\title{
Molecular Targets and Promising Therapeutics of Triple-Negative Breast Cancer
}

\author{
Won-Ji Ryu ${ }^{1}$ (D) and Joo Hyuk Sohn ${ }^{2, *}$ \\ 1 Avison Biomedical Research Center, Yonsei University College of Medicine, Seoul 03722, Korea; \\ wjryu711@yuhs.ac \\ 2 Division of Medical Oncology, Department of Internal Medicine, Yonsei University College of Medicine, \\ Seoul 03722, Korea \\ * Correspondence: ONCOSOHN@yuhs.ac; Tel.: +82-02-2228-8135
}

Citation: Ryu, W.-J.; Sohn, J.H.

Molecular Targets and Promising

Therapeutics of Triple-Negative

Breast Cancer. Pharmaceuticals 2021 14, 1008. https://doi.org/10.3390/ ph14101008

Academic Editors:

Maryam Nakhjavani and

Amanda Townsend

Received: 30 August 2021

Accepted: 27 September 2021

Published: 30 September 2021

Publisher's Note: MDPI stays neutral with regard to jurisdictional claims in published maps and institutional affiliations.

Copyright: (c) 2021 by the authors. Licensee MDPI, Basel, Switzerland. This article is an open access article distributed under the terms and conditions of the Creative Commons Attribution (CC BY) license (https:// creativecommons.org/licenses/by/ $4.0 /)$.

\begin{abstract}
Triple-negative breast cancer (TNBC) is one of the most heterogeneous diseases in solid tumors and has limited therapeutic options. Due to the lack of appropriate targetable markers, the mainstay therapeutic strategy for patients with TNBC has been chemotherapy for the last several decades. Indeed, TNBC tumors have no expression of estrogen receptor, progesterone receptor, or human epidermal growth factor receptor 2 (HER2); therefore, they do not respond to hormone therapy and HER2-targeted therapy. In this review paper, the molecular heterogeneities, possible therapeutic targets, and recently approved and upcoming drugs for TNBC will be summarized.
\end{abstract}

Keywords: triple-negative breast cancer; heterogeneity; molecular target; new drugs

\section{Introduction}

Breast cancer is a heterogenous disease. Hormone receptor-positive breast cancer, covering luminal A and luminal B subtypes (70-80\%) in gene expression profiles, is quite dependent on the hormone receptor pathway, so its mainstream treatment is endocrine therapy with or without targeted agents to interrupt estrogen-signaling pathways and other critical pathways, such as cyclin-dependent kinase (CDK) $4 / 6$ and phosphoinositide 3-kinase (PI3K)-AKT-mechanistic target of rapamycin (mTOR) pathway, for cancer survival. Human epidermal growth factor receptor 2 (HER2)-positive breast cancer comprises a HER2-enriched subtype and luminal B subtypes (10-15\%) in molecular profiling and is addicted to the HER2 oncogene; thus, HER2-targeted therapies combined with cytotoxic chemotherapy are regarded as the standard treatment. By contrast, triple-negative breast cancer (TNBC) lacks these three receptors (estrogen receptor (ER), progesterone receptor (PR), and HER2) and, thus, is a diagnosis of exclusion showing the basal subtype in molecular profiling. In addition, due to advanced "multi-omics" technology, TNBC itself has been revealed to be a heterogeneous disease with several subtypes according to cancer biology [1].

Given that only $10-15 \%$ of all breast cancer cases are TNBC, further classification into smaller subgroups has not been clinically practical. Therefore, most of the clinical trials with targeted agents for TNBC included all TNBC subtypes, even after full awareness of it as a heterogeneous disease [2,3]. Basically, it would be difficult to obtain a meaningful result in these trials since a specifically targeting agent won't work on such a mixed group of diseases. Recently, there have been several trials that limited enrollment to only participants with a particular subtype, who are most likely to respond to the targeted agent. One good example is poly (ADP-ribose) polymerase (PARP) inhibitors for TNBC patients with germline $B R C A 1 / 2$ mutations, accounting for approximately $10 \%$ of TNBC patients. [4-6]. In this regard, this review discusses molecular targets and recently proved and upcoming therapeutics of TNBC. 


\section{Molecular Subtypes of TNBC}

With the development of "omics" (transcriptomic and genomic) technology, breast cancers were classified into the following five intrinsic subtypes (PAM50) by analyzing their gene expression pattern rather than the receptor expression status: basal-like, luminal A or B, HER2enriched, or normal-like [2,3,7]. These pivotal studies found that breast cancers with triple-negative characteristics do not always overlap with the basal-like subtype, which means that although approximately $90 \%$ of TNBC cases are basal-like breast cancer (BLBC) [8], the rest of TNBC cases show the other breast cancer subtypes, such as HER2 enriched or luminal B subtypes.

Studying genetic and molecular heterogeneity of patients with TNBC, Lehmann and a group of colleagues [9] defined six TNBC subtypes according to gene expression clustering: basal-like 1 (BL1), basal-like 2 (BL2), mesenchymal (M), mesenchymal stem-like (MSL), immunomodulatory (IM), and luminal androgen receptor (LAR) (Table 1).

Table 1. Characteristics and potential therapies of TNBC subtype.

\begin{tabular}{|c|c|c|c|c|c|}
\hline TNBC Subtype & Histology & Characteristics & $\begin{array}{c}\text { Molecular and Pathway } \\
\text { Alterations }\end{array}$ & Potential Therapeutics & Reference \\
\hline Basal-like 1 & $\begin{array}{l}\text { Ductal carcinoma and } \\
\text { invasive ductal } \\
\text { carcinoma tumors }\end{array}$ & $\begin{array}{l}\text { Cell-cycle-regulating } \\
\text { and DNA repair } \\
\text { pathway }\end{array}$ & $\begin{array}{l}\text { MYC, PIK3CA, KRAS, } \\
\text { FGFR1, AKT2, BRCA1, } \\
\text { TP53, and RB1 } \\
\text { amplifications }\end{array}$ & $\begin{array}{c}\text { Platinum salts } \\
\text { (carboplatin, cisplatin, etc.) } \\
\text { PARP inhibitors } \\
\text { (olaparib, talazoparib, etc.) }\end{array}$ & {$[4,5,9-16]$} \\
\hline Basal-like 2 & $\begin{array}{l}\text { Ductal carcinoma and } \\
\text { invasive ductal } \\
\text { carcinoma tumors }\end{array}$ & $\begin{array}{l}\text { Cell-growth-related } \\
\text { pathway }\end{array}$ & $\begin{array}{c}\text { EGFR, MET, } \\
\text { Wnt/b-catenin, mTOR, } \\
\text { and IGF1R pathways }\end{array}$ & $\begin{array}{c}\text { Platinum salts } \\
\text { (carboplatin, cisplatin, etc.) } \\
\text { PARP inhibitors } \\
\text { (olaparib, talazoparib, etc.) } \\
\text { Growth factor inhibitors } \\
\text { (lapatinib, gefitinib, and } \\
\text { cetuximab) }\end{array}$ & {$[9,10,17-19]$} \\
\hline Immunomodulatory & Medullary tumors & $\begin{array}{l}\text { Immune-cell-associated } \\
\text { signaling pathway }\end{array}$ & $\begin{array}{l}\text { CTLA4, NK cell, } \\
\text { Th1/Th2, NF-kB, TNF, T } \\
\text { cell signaling, dendritic } \\
\text { cell, and BCR pathways }\end{array}$ & $\begin{array}{c}\text { Immune checkpoint inhibitors } \\
\text { (pembrolizumab, } \\
\text { atezolizumab, and others) }\end{array}$ & {$[10,20-27]$} \\
\hline Mesenchymal like & $\begin{array}{l}\text { Sarcoma-like and } \\
\text { squamous epithelial } \\
\text { cell-like tumors }\end{array}$ & $\begin{array}{l}\text { Cell migration- and } \\
\text { ECM-related pathway }\end{array}$ & $\begin{array}{l}\text { Wnt, TGFb, and ECM } \\
\text { pathways }\end{array}$ & $\begin{array}{c}\text { Tyrosine kinase inhibitors, } \\
\text { mTOR inhibitor, EMT inhibitor } \\
\text { (eribulin mesylate) }\end{array}$ & {$[9,28]$} \\
\hline Mesenchymal stem-like & $\begin{array}{l}\text { Sarcoma-like and } \\
\text { squamous epithelial } \\
\text { cell-like tumors }\end{array}$ & $\begin{array}{c}\text { Stem-cell-related } \\
\text { pathway }\end{array}$ & $\begin{array}{l}\text { BMP2, ENG, ITGAV, } \\
\text { NGFR, PDGFR, THY1, } \\
\text { KDR, and VCAM1 }\end{array}$ & $\begin{array}{l}\text { PI3K inhibitor, Src antagonists, } \\
\text { antiangiogenic drugs }\end{array}$ & {$[9,29]$} \\
\hline $\begin{array}{l}\text { Luminal androgen } \\
\text { receptor }\end{array}$ & Apocrine tumors & $\begin{array}{l}\text { Hormone-related } \\
\text { pathway }\end{array}$ & $\begin{array}{l}\text { Androgen and estrogen } \\
\text { metabolism, steroid } \\
\text { biosynthesis, tyrosine } \\
\text { metabolism, and ATP } \\
\text { synthesis }\end{array}$ & $\begin{array}{l}\text { Anti-androgen therapies } \\
\text { (bicalutamide, } \\
\text { enzalutamide, etc.) }\end{array}$ & [30-35] \\
\hline
\end{tabular}

The BL1 subtype exhibits abnormal expression of genes related to cell cycle regulation and DNA repair (MYC, PIK3CA, KRAS, FGFR1, AKT2, BRCA1, TP53, and RB1) [9,36]. The BL2 subtype shows abnormal activation in various pathways related to cell growth (EGFR, MET, Wnt/b-catenin, mTOR, and IGF1R pathways) $[9,36]$. The IM subtype is marked by several activated pathways involved in immune cell signaling: CTLA4, NK cell, Th1/Th2, NF-kB, TNF, T cell signaling, dendritic cell, and BCR pathways. The histological phenotype of IM tumors is similar to medullary breast cancer [9,37]. In the M subtype, the cell migration or epithelial-mesenchymal transition (EMT)-related Wnt, TGFb, and extracellular matrix (ECM) pathways are highly activated. The MSL subtype exhibits a higher expression of stemness-related genes than the M subtype. The histological characteristics of these mesenchymal subtypes are sarcoma-like or squamous epithelial cell-like phenotypes, and they overlap with metaplastic breast cancer [9]. The LAR subtype does not express ER and PR, but hormone-related pathways are activated, such as androgen and estrogen metabolism, steroid biosynthesis, tyrosine metabolism, and ATP synthesis [9]. For the LAR subtype, androgen receptor (AR) expression is confirmed through immunohistochemistry. This subtype shows a gene expression pattern that is the unique from other TNBC subtypes and its histological type is similar to an apocrine tumor [11]. 
The TNBC subtypes were further compared with the intrinsic molecular (PAM50) subtypes to analyze their relevance [36]. Most TNBC subtypes were classified as basal-like subtypes in PAM50-based profiling (BL1, 99\%; BL2, 95\%; IM, 84\%; and M, 97\%), except for MSL (basal-like, 50\%; normal-like, 28\%; and luminal B, 14\%) and LAR (HER2-enriched, $74 \%$; and luminal $\mathrm{B}, 14 \%$ ) subtypes. Furthermore, in order to discover a new subtypespecific target, recent studies have attempted to reanalyze TNBC molecular profiles for classification $[38,39]$.

\section{Potential Molecular Targets of TNBC}

\subsection{DNA Repair Pathway}

BRCA1 and BRCA2 are considered to be tumor suppressor genes. They are critical for maintaining DNA replication error control, cell division, DNA repair, and apoptosis involving the homologous recombination repair pathway $[17,18]$. The germline mutation of $B R C A 1$ or $B R C A 2$ carriers ultimately develop breast cancer in $60-70 \%$ in their lifetime, and their mutation in TNBC occurs with a frequency of $10 \%$ [4,5,12]. Interestingly, tumors with the basal-like phenotype have been frequently observed harboring $B R C A 1$ mutations, while ER-positive breast cancers are closely correlated with $B R C A 2$ mutations $[13,14]$.

$B R C A 1$ and $B R C A 2$ have a critical role in double-strand break repair via the homologous recombination pathway (Figure 1). Patients with the germline mutations of these genes show a loss of heterozygosity and pathologically high-grade tumors [40]. Tumors with these mutations are sensitive to DNA-damaging drugs and show a selective toxicity to the inhibitors of PARP responsible for single-strand break repair [6].

In addition to BRCA1/2, the DNA repair pathway is also regulated by many other proteins, such as ATM, PALB2, RAD51, BARD1, BRIP1, PARP1, TP53, and CHK2 [30,41]. Therefore, the homologous recombination deficiency (HRD) phenotype has been observed in tumors without mutations of $B R C A 1$ and $B R C A 2$, which have been defined as "BRCAness" [4,5]. Some BRCA-proficient TNBC patients have shown this HRD phenotype and a high response to DNA-crosslinking agents [31,42]. 


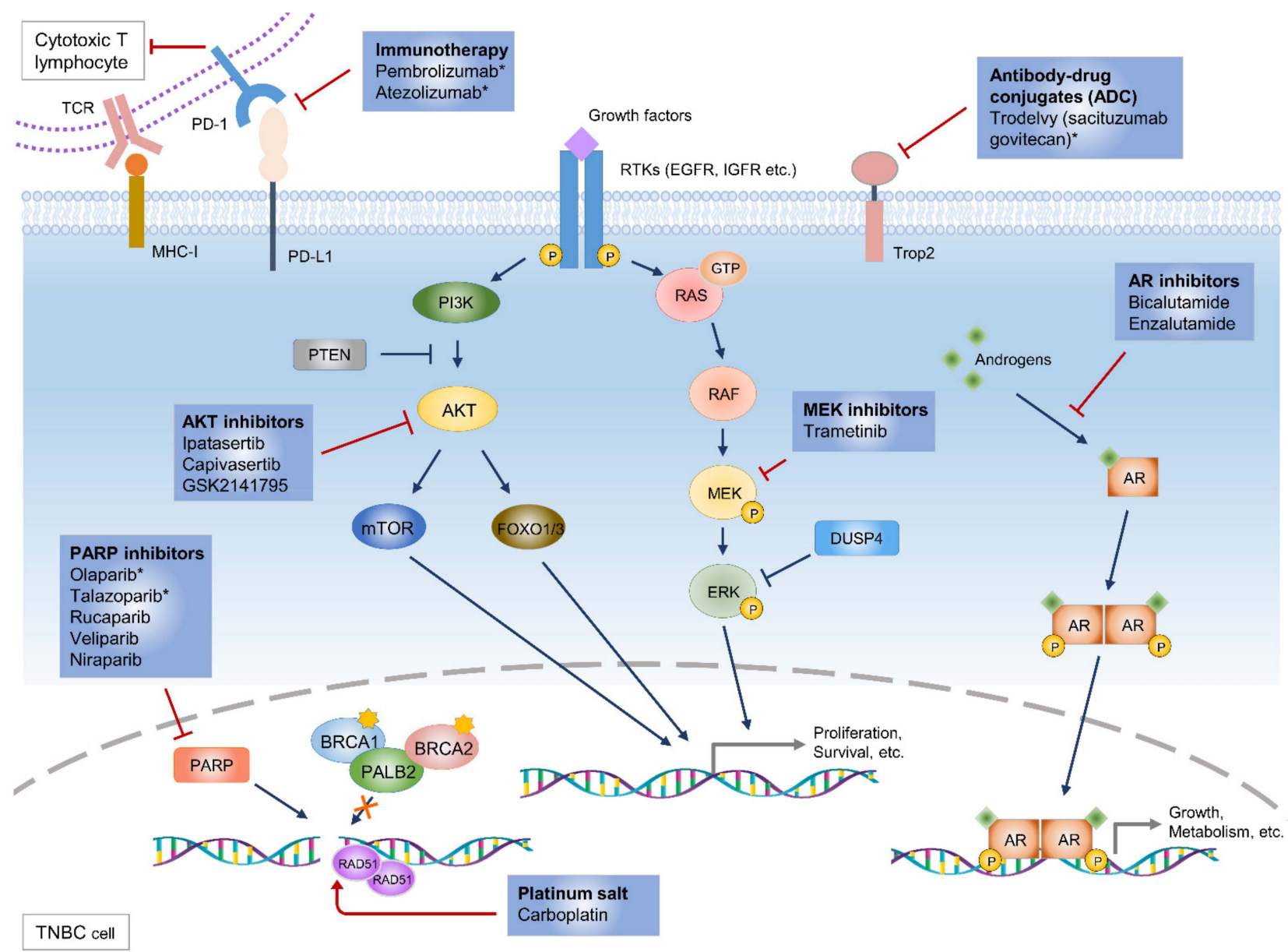

Figure 1. Scheme of potential molecular targets and therapeutic agents including FDA-approved and upcoming targeted therapies in TNBC. Extracellular stimuli, such as growth factors, initiate PI3K/AKT and RAS/MAPK signaling pathways to activate transcription of target genes involved in proliferation, survival, and tumorigenesis. There are potential targeted therapeutics that inhibit these pathways, including AKT inhibitors or MEK inhibitors. In the case of TNBC tumors harboring BRCA1/2 mutations, PARP replaces them, allowing DNA damage to repair and tumor cells to survive. Thus, PARP inhibitors are commonly prescribed for BRCA1/2 mutated TNBC patients. Carboplatin, a platinum salt, induces DNA crosslink strand breaks and causes the apoptosis of tumor cells with a dysfunctional repair pathway. Androgen receptor (AR) is activated by binding of androgen, triggering dimerization and translocation of androgen-AR complex to stimulate cell growth and metabolism in TNBC. AR inhibitors compete with androgens to bind AR and block the AR signaling pathway. Cytotoxic T-lymphocytes recognize the neo-antigen of tumor cells binding to major histocompatibility complex (MHC)-I and kill the tumor cells. To avoid anti-cancer immunity of cytotoxic T-lymphocytes, TNBC tumor cells exhibit anti-programmed death ligand 1 (PD-L1), which binds to PD-1 of the T-lymphocyte. Immunotherapeutic antibodies have been introduced to suppress immune evasion in TNBC tumors. Recently, antibody-drug conjugates (ADC) have been approved by the FDA for clinical use in TNBC. Blue arrow: signaling transduction, red arrow: action of blockers and inhibitors, yellow star: mutations, yellow circle: phosphorylation, orange circle: neo-antigen peptide, ${ }^{*}$ : U.S. Food and Drug Administration (FDA)-approved drugs.

\subsection{PI3K/AKT Pathway}

The PIK3CA mutation (10.2\%) is the second major gene aberration, followed by the TP53 mutation, found in patients with TNBC [4,5]. These hotspot mutations in the PIK3CA gene induce the abnormal activation of the PI3K pathway (Figure 1). PTEN loss (9.6\%), a negative regulator of the PI3K pathway, has a mutually exclusive relationship with the PIK3CA mutation [5]. These alterations result in the activation of AKTs, which could be attractive targets for TNBC therapy. 
In addition, PI3K plays a role of binding and stabilizing double-strand breaks via interaction with the homologous recombinant complex [43]. Therefore, the inhibition of PI3K results in homologous recombination impairment and then makes a state similar to a BRCA1/2-deficient tumor. Consistent with this observation, blocking PI3K could make TNBC tumors more sensitive to PARP inhibitors or DNA-damaging agents.

\subsection{RAS/MAPK Pathway}

Aberrant mutations in major factors of the RAS/MAPK pathways are rare in patients with TNBC $[4,9,44]$. However, gain-of-function mutations of RAF, HRAS, and KRAS have been found in some TNBC cell lines [45]. In addition, TNBC cell lines without these mutations have also been reported to show increased activation of the RAS/MAPK pathway (Figure 1).

The overexpression of epithelial growth factor receptor (EGFR) is known to be a common feature of BLBC and TNBC [32]. As an upstream molecule of the RAS/MAPK pathways, EGFR has an important role in signaling transduction. The gene copy number alteration of EGFR is highly increased in patients with TNBC [33]. In addition, various tyrosine kinase receptors, such as FGFR1, IGF1R, ERRB3, and ERBB4, are upregulated in TNBC [32].

In the RAS/mitogen-activated protein kinase (MAPK) pathway, one of the targetable proteins for patient with TNBC is MEK. TNBC and BLBC cell lines tend to be more sensitive to MEK inhibitors than other subtypes [46]. In addition, MEK is known to regulate the stability of c-Myc, which can be degraded after treatment with MEK inhibitor in TNBC [47,48]. However, the degradation of c-MYC via single agent MEK inhibition has an adverse effect that induces the activation of receptor tyrosine kinases (RTKs) [48]. Further studies are needed to overcome the resistance of single treatment with MEK by combining it with RTKs-targeted monoclonal antibodies.

Another cause of RAS/MAPK pathway activation is the loss of the dual specificity phosphatase 4 gene (DUSP4), a negative regulator of extracellular signal-regulated kinase $1 / 2$ (ERK1/2) and c-Jun N-terminal kinase 1/2 [49]. In particular, DUSP4 is known to be associated with the activation of the RAS/MAPK pathway in the BLBC subtype. In preclinical studies, it was found that resistance to chemotherapeutic agents is induced via the loss of its function, negatively regulating the RAS/MAPK pathway [49]. The loss of DUSP4 enhances the maintenance of cancer stem cell populations, which can be abolished when treated with the inhibitors of the RAS-ERK pathway [50].

\subsection{Androgen Receptor Pathway}

The LAR subtype shows nine times higher mRNA expression of the AR than the other TNBC subtypes, predisposing LAR tumors to be susceptible to AR antagonists [9]. AR is expressed in $10-50 \%$ of patients with TNBC [51-53]. Patients with the LAR subtype tend to have a poor chemotherapy response and rarely achieve pathological complete response (pCR) in neoadjuvant chemotherapy [19,54,55].

$\mathrm{AR}$ is one of the steroid hormone receptors in the nuclear receptor family. In the absence of androgen, AR localizes to the cytosol, but after ligand binding, the receptorhormone complex moves to the nucleus and increases the expression of the target genes (Figure 1) [56,57]. In addition, AR signaling is also activated through ERK-mediated signaling with PI3K, Src, and RAS [58,59]. LAR-subtype TNBC cell lines with increased AR expression were found to frequently carry PIK3CA-activating mutations, demonstrating a correlation between AR dependency and the PI3K pathway [60]. In addition to AR inhibitors, these cells are sensitive to PI3K inhibitors, as ER-positive breast cancer cells with PIK3CA mutations succumb to PI3K inhibitors such as alpelisib [61].

\subsection{Other Pathways}

Various studies are ongoing to identify candidates targeting metastatic TNBC. One of the targets is epigenetic DNA methylation. The methylation on BRCA1 promoter is corre- 
lated with poorer overall survival (OS) and recurrence-free survival (RFS) in TNBC [62]. A recent clinical study reported that hypermethylation patterns can predict higher $\mathrm{pCR}$ rate after neoadjuvant chemotherapy in patients with TNBC [63]. Phase I/II studies of histone deacetylase inhibitors have been under investigation for patients with metastatic TNBC (NCT02393794).

Breast cancer stem cells have been considered as a primary cause of recurrence and metastasis due to the repopulating ability from a single cell [64]. Breast cancer stem cells have a slower growth rate than breast cancer non-stem cells, making them less responsive to chemotherapy [65]. In TNBC, BLBC subtype cells are known to be enriched with cancer stem cells. Preclinical and clinical studies have shown that Wnt/b-catenin [28], Notch [66], Hedgehog [67], JAK/STAT [68], and RAS/MAPK [50,69] pathways could enhance breast cancer stem cell populations.

\section{Immune System in TNBC}

The major cancer-related immune response is adaptive immunity, including cytotoxic CD8 T-lymphocyte in the immune microenvironment of cancer. The genomic abnormality of cancer causes the presentation of neo-antigenic peptide binding to major histocompatibility complex (MHC) on the surface of tumor cells. As a result, cytotoxic T-lymphocytes recognize the neo-antigenic peptide and lyse the tumor cells.

Breast cancer shows a high level of genomic instability and could stimulate cancerrelated immune system. A representative phenomenon of immunogenic activation is lymphocytic infiltration in the tumor microenvironment. TNBC has a tendency to show a higher level of tumor-infiltrating lymphocytes (TILs) than the other breast cancer subtypes $[10,70]$. TNBC is subject to showing higher genomic instability and mutation burden, which stimulates the adaptive immune system through presenting a number of neo-antigens [71]. Especially, the level of TILs has a clinical importance for predicting response to chemotherapy and survival rate in TNBC [72,73]. TNBC patients who have more than $50 \%$ of TILs in the tumor showed about $40 \%$ of pCR, whereas those with no TILs showed $4 \%$ of pCR [74]. In addition, disease-free survival (DFS) and OS were improved in the patients with a high level of TILs [10]. The survival of TNBC patients was increased in a group showing numerous CD8 T-lymphocytes among the TILs compared to those showing few CD8 T-lymphocytes [15,75]. However, a therapeutic strategy to increase the number of TILs is needed to improve survival and therapeutic effect, since only small proportion of TNBCs show a high TIL rate.

Recently, neutrophil-lymphocyte ratio (NLR) has been reported as another prognostic marker predicting clinical outcomes in cancer immunology. Neutrophils have been known to facilitate angiogenesis and disease progression, which increases the possibility of metastasis and recurrence [76,77]. Furthermore, neutrophils inhibit the anti-cancer immunity of T-lymphocytes and natural killer cells [78]. Recent studies showed that the level of NLR in a neoadjuvant chemotherapy setting has prognostic value for $\mathrm{PCR}$ in TNBC patients [79-81]. Furthermore, a high level of NLR was adversely correlated with DFS and OS [79].

Although there is no clearly defined prognostic marker for predicting the disease progression of TNBC patients, clinical evidence continues to show that the analysis of patients' immune systems can predict the response to and survival of chemotherapy. Overall, early identification of a patient's immune environment could be a potential therapeutic strategy for TNBC.

\section{Available New Drugs}

\subsection{Carboplatin}

Carboplatin, a type of platinum salt, induces DNA crosslink strand breaks and results in apoptosis of cells with a dysfunctional repair pathway (Figure 1). Originally, platinum chemotherapeutic agents showed only a modest response in breast cancer except for chemotherapy-naïve tumors $[16,82]$. Therefore, these drugs were much more available for other cancer types, such as ovarian cancer, than breast cancer. However, the method of 
classifying TNBC subtype revealed that the BLBC subtype, which accounts for most TNBC tumors, has the characteristics of genomic instability, BRCA1 abnormalities, defected DNA repair pathway, and replication stress. These features are similar to those observed in ovarian cancer [83]. Preclinical and clinical data have accumulated to examine again the effect of platinum agents for TNBC [84].

A multicenter phase II clinical trial evaluated platinum monotherapy to assess biomarkers for patients with metastatic TNBC [85]. Carboplatin and cisplatin showed overall response rates (ORRs) of $18.7 \%$ and $32.6 \%$, respectively. Patients harboring $B R C A 1 / 2$ mutations $(n=11)$ had a higher ORR $(54.5 \%)$ than those without $B R C A 1 / 2$ mutations $(n=66$; ORR, 19.7\%). In addition, the HRD score was shown to discriminate between responding and non-responding groups to platinum agents in metastatic TNBC.

A phase III Triple-Negative breast cancer Trial (TNT) evaluated the efficacy of either carboplatin or docetaxel in 376 unselected patients with metastatic TNBC [86]. In a randomly distributed population ( $n=376 ; 188$ carboplatin and 188 docetaxel), there was no evidence that carboplatin has a better response rate than docetaxel (ORR, 31.4\% and $34.0 \%$, respectively; $p=0.66)$. However, in patients with germline $B R C A 1 / 2$ mutations, the carboplatin-treated group had a higher ORR (68\%) than the docetaxel-treated group (ORR, $33 \%)$. Interestingly, this responsiveness was not found in those with BRCA1 methylation, low expression of BRCA1 mRNA, or high HRD score tumors [86]. Although the patients with PAM50 basal tumors did not show a better response to carboplatin than docetaxel (ORR, 32.5\% vs. 31.0\%; $p=0.78$ ), those with non-basal-like tumors had a better response to docetaxel than carboplatin (ORR, $72.2 \%$ vs. $16.7 \% ; p=0.002)$. Thus, this study did not reveal molecular evidence to identify who will benefit from treatment with a platinum agent, besides the germline BRCA1/2 mutation status.

Recently, clinical trials of neoadjuvant carboplatin treatment were released in TNBC showing increased pCR in the carboplatin-added arm [87,88]. The phase II trial (NCT01525966) evaluated the efficacy of neoadjuvant carboplatin with combinatory nab-paclitaxel in early stage TNBC, newly diagnosed stage II- III [87]. Sixty-seven patients were enrolled in this study and showed manageable toxicity. The combination of carboplatin and nabpaclitaxel was highly effective in TNBC, and 32 of 67 patients (48\%) showed pCR. In addition, higher pCR was associated with "immune-hot" GeparSixto immune signature (GSIS; $p=0.005$ ) [89] and DNA repair defect (DRD; $p=0.03$ ). However, BRCA status did not show a significant correlation with pCR. GSIS includes 12 immune genes (CCL5, CXCL9, CXCL13, CD80, CD21, CD8A, IGKC, PD-1, CD274 (PD-L1), CTLA4, FOXP3, and IDO1). The result of this study showed that those genes have a potential to be used as clinical markers for the combinatory treatment of carboplatin and nab-paclitaxel. The benefit of carboplatin in early-stage TNBC patients provides a rationale to use platinum-based therapy for (neo)adjuvant treatment, but only currently ongoing randomized phase 3 trials could answer definitely regarding event-free survival (PEARLY trial: NCT02441933; NRG-BR003 trial: NCT02488967)

\subsection{PARP Inhibitor}

PARP is an essential enzyme for DNA repair, cell proliferation, and signaling to other cell-cycle proteins through the mechanism of action of transferring ADP-ribose from NAD+ to target proteins $[90,91]$. In replicating cells, the inhibition of PARP induces double-strand breaks; therefore, PARP inhibitors have selective toxicity in BRCA1/2-deficient cells with impaired homologous recombination [6].

Olaparib is the first approved PARP inhibitor with an advanced efficacy for patients with germline BRCA-mutated metastatic breast cancer (gBRCAm-BC) (Figure 1 and Table 2). This approval was based on result from OlympiAD [92], an open-label and randomized phase III trial $(n=302)$ evaluating olaparib compared with chemotherapies (capecitabine, vinorelbine, or eribulin). Median progression-free survival was significantly longer in the olaparib group than in the standard therapy group (7.0 months vs. 4.2 months; hazard ratio (HR), 0.58; 95\% confidence interval (CI), 0.43-0.80; $p<0.001$ ). Patients treated 
with olaparib monotherapy $(n=205)$ had a higher response rate than those with the standard-therapy ( $n=97 ; 59.9 \%$ vs. $28.8 \%)$.

Table 2. Drugs approved by FDA for patients with TNBC.

\begin{tabular}{|c|c|c|c|c|c|}
\hline Drug Name & Target & Dosage Form & FDA Approved Date & $\begin{array}{l}\text { Clinical Study } \\
\text { Number }\end{array}$ & Study \\
\hline Olaparib & PARP & Chemical & January, 2018 & NCT02000622 & [92] \\
\hline Talazoparib & PARP & Chemical & October, 2018 & NCT01945775 & [93] \\
\hline Pembrolizumab & PD-1 & $\begin{array}{l}\text { Monoclonal } \\
\text { antibody }\end{array}$ & November, 2020 & NCT02819518 & [24] \\
\hline Atezolizumab & PD-L1 & $\begin{array}{l}\text { Monoclonal } \\
\text { antibody }\end{array}$ & March, 2019 & NCT02425891 & [27] \\
\hline $\begin{array}{c}\text { Trodelvy } \\
\text { (sacituzumab } \\
\text { govitecan) }\end{array}$ & $\begin{array}{c}\text { Trop2, } \\
\text { Topoisomerase I }\end{array}$ & $\mathrm{ADC}$ & April, 2020 & NCT01631552 & [94] \\
\hline
\end{tabular}

The EMBRACA study evaluated talazoparib, another PARP inhibitor, for patients with gBRCAm-BC (NCT01945775) [93]. The randomized and open-label trial assigned the patients to receive talazoparib or standard chemotherapies (capecitabine, eribulin, or vinorelbine) in a 2:1 ratio. The talazoparib group showed longer median progressionfree survival (PFS) than the standard chemotherapy group (8.6 months vs. 5.6 months; $\mathrm{HR}=0.542 ; p<0.001)$. The ORR was also higher in the talazoparib group than in the standard chemotherapy group $(62.6 \%$ vs. $27.2 \% ; p<0.001)$. The results of this trial showed that talazoparib had a significant benefit compared with the standard chemotherapy for patients with advanced breast cancer and germline BRCA mutations, which contributed to the U.S. Food and Drug Administration (FDA)'s approval of talazoparib (Table 2).

Other PARP inhibitors are currently being evaluated in clinical trials: rucaparib (NCT01074970), veliparib (NCT02163694), and niraparib (NCT01905592).

\subsection{Immumotherapy}

Using the immune check point mechanism, tumor cells have the ability to evade recognition and cell death by the host's adaptive immune system. Thus, this mechanism is considered to be a therapeutic target for effective antitumor immunity. Major checkpoint molecules are programmed cell death ligand 1 (PD-L1) and programmed cell death protein 1 (PD-1). PD-L1 on the surface of tumors bind to PD-1 of cytotoxic T cells (Figure 1), inducing signal transduction to inhibit $\mathrm{T}$ cell activation and cause immune tolerance [95]. Although breast cancer has not been known as actively immunogenic tumors, TNBC shows a higher number of tumor-infiltrating lymphocytes, which are regarded as the prognostic marker for antitumor immunotherapies [10], as well as higher PD-L1 expression [20,21] than other breast cancer types.

These results led to clinical trials testing the efficacy of immunotherapies in advanced and metastatic TNBC. Pembrolizumab, an anti-PD-1monoclonal antibody, was evaluated in the phase II KEYNOTE-086 trial in patients with advanced TNBC who had three prior chemotherapies showing an encouraging ORR (23.1\%) in PD-L1 positive [22,23]. Subsequently, pembrolizumab was approved based on the results of the KEYNOTE-355 (NCT02819518) double-blind and randomized trial with patients with locally recurrent, unresectable, or metastatic TNBC without previous chemotherapy treatment (Table 2) [24]. Patients who received pembrolizumab plus chemotherapy had significantly longer median PFS than those receiving placebo plus chemotherapy (9.7 months vs. 5.6 months; HR 0.65; 95\% CI: 0.49-0.86; one-sided $p=0.0012$ ). 
Furthermore, the effect of pembrolizumab on patients with early TNBC was investigated in the phase III KEYNOTE-522 trial [25]. Pembrolizumab was used to treat stage II or stage III TNBC patients with neoadjuvant chemotherapy. The rate of patients with a pCR was $64.8 \%$ in the pembrolizumab-chemotherapy group and $51.2 \%$ in the placebochemotherapy group (treatment difference: $13.6 \%, 95 \%$ CI, 5.4 to $21.8 ; p<0.001$ ). This study showed that neoadjuvant chemotherapy plus pembrolizumab could significantly improve pCR in early TNBC patients, with statistically significant enhanced event-free survival [25]. However, in the KEYNOTE-119 trial, single treatment with pembrolizumab did not show significant improvement compared to chemotherapy in metastatic TNBC patients who failed first-line therapy [26].

Similarly, an anti-PD-L1 monoclonal antibody, atezolizumab, was also approved in combination with protein-bound paclitaxel for patients with unresectable locally advanced or metastatic TNBC without prior chemotherapy based on the Impassion130 (NCT02425891) trial (Table 2) [27]. In patients expressing PD-L1, those who received atezolizumab with protein-bound paclitaxel exhibited significantly longer PFS than those receiving the placebo with protein-bound paclitaxel ( 7.4 months vs. 4.8 months; $p=0.002)$. The ORR was $53 \%$ for the atezolizumab arms, compared with $33 \%$ for the placebo arms. Furthermore, the PD-L1-positive population showed better median OS (25.0 months vs. 15.5 months; HR, $0.62 ; 95 \%$ CI, 0.45-0.86).

\subsection{Antibody-Drug Conjugates}

Antibody-drug conjugates (ADCs) are attracting attention as a new anticancer therapy that can payload cytotoxic drugs on monoclonal antibodies through specific linkers. ADCs can specifically deliver high-dose cytotoxic drugs precisely to cancer cells. Recently, novel ADCs have entered clinical studies to evaluate their efficacy for patients with TNBC.

An anti-trophoblast cell surface antigen 2 (Trop2) ADC, Trodelvy (sacituzumab govitecan), was FDA approved for the treatment of TNBC patients who have received at least two prior therapies (Table 2). Trop2 has recently shown potential as a therapeutic target due to its specific overexpression in cancer cells [96]. It is also involved in embryonic development and oncogenic signaling pathways, such as the MAPK-ERK $1 / 2$ pathway $[97,98]$. Trodelvy is the anti-Trop2 humanized monoclonal antibody linked to SN-38, an irinotecan metabolite known as a topoisomerase I inhibitor, through a maleimide-polyethylene glycolacid-sensitive cleavable (carbonate) linker [34,99]. Following accelerated approval based on results of a phase II clinical trial, the randomized phase III ASCENT (NCT01631552) trial showed longer PFS with sacituzumab govitecan than with standard chemotherapy, leading to approval of the new ADC for refractory metastatic TNBC [94]. Patients treated with sacituzumab govitecan $(n=108)$ showed a PFS of 5.5 months, whereas those with standard chemotherapy had a PFS of 1.7 months (HR, $0.41 ; p<0.0001)$.

Furthermore, there is another promising ADC, trastuzumab deruxtecan (T-DXd, formerly DS-8201a). T-DXd is a HER2-targeted ADC payloaded with topoisomerase I inhibitor, an exatecan derivative [35]. The phase I study of T-DXd was conducted in TNBC patients with HER2-low tumors (defined as IHC 1+/ISH negative or 2+/ISH negative), as well as strong HER2-positive breast cancers [35]. HER2-low breast cancer patients $(n=54)$ showed $37 \%$ of the independent-central-review-confirmed ORR and $44.4 \%$ of the investigator-reported-confirmed ORR, with a median response duration of 10.4 months. This trial indicated that patients with HER2-low breast cancer could benefit from this novel HER2-targeted ADC, and currently, a phase 3 trial is ongoing.

\section{Upcoming and Potential Targeted Therapies}

\subsection{AKT Inhibitor}

Aberrant activation of the PI3K/AKT pathway is frequently shown in TNBC patients (Figure 1), which suggests that AKT inhibitors might be effective for those patients (Table 3). The randomized phase II clinical trial of ipatasertib, an AKT inhibitor, with paclitaxel was evaluated in TNBC patients as first-line treatment (NCT02162719; LOTUS) [29]. Patients 
treated with paclitaxel/ipatasertib $(n=62)$ showed longer median PFS than those with paclitaxel/placebo ( $n=62 ; 6.2$ months vs. 4.9 months; $p=0.037)$. Especially in the group of PIK3CA, AKT1, and PTEN-altered patients $(n=42)$, ipatasertib had better PFS than those treated with placebo ( 9.0 months vs 4.9 months). The ongoing phase II and III clinical trials are evaluating the efficacy of ipatasertib in combination with paclitaxel for PIK3CA/AKT1/PTEN-altered TNBC (NCT03337724; IPATunity130).

Table 3. Ongoing clinical trials of upcoming targeted therapies for patients with TNBC.

\begin{tabular}{|c|c|c|c|c|c|c|}
\hline Targets & Disease Setting & $\begin{array}{l}\text { Breast Cancer } \\
\text { Subtype }\end{array}$ & Phase & Therapies (Alone or Combination) & Control Treatment & $\begin{array}{c}\text { Clinical Trial } \\
\text { Reference Number }\end{array}$ \\
\hline \multirow{3}{*}{ AKT } & Metastatic & TNBC & II & Ipatasertib (GDC-0068) + paclitaxel & Paclitaxel & NCT02162719 \\
\hline & $\begin{array}{l}\text { Locally advanced or } \\
\text { metastatic }\end{array}$ & $\begin{array}{l}\text { TNBC or hormone } \\
\text { receptor-positive, } \\
\text { HER2-negative BC }\end{array}$ & III & Ipatasertib + paclitaxel & Paclitaxel & NCT03337724 \\
\hline & $\begin{array}{l}\text { Locally advanced } \\
\text { (inoperable) or } \\
\text { metastatic }\end{array}$ & TNBC & III & Capivasertib (AZD5363) + paclitaxel & Paclitaxel & NCT03997123 \\
\hline \multirow{3}{*}{ Androgen } & Neoadjuvant & $\begin{array}{c}\text { Androgen } \\
\text { receptor-positive } \\
\text { TNBC }\end{array}$ & $\mathrm{IIlb}$ & Enzalutamide + paclitaxel & Paclitaxel & NCT02689427 \\
\hline & Metastatic & $\begin{array}{c}\text { Triple negative, } \\
\text { androgen receptor } \\
\text { positive BC }\end{array}$ & $\mathrm{I} / \mathrm{II}$ & Bicalutamide + palbociclib & NA & NCT02605486 \\
\hline & Metastatic & $\begin{array}{l}\text { Androgen } \\
\text { receptor-positive } \\
\text { TNBC }\end{array}$ & $\mathrm{Ib} / \mathrm{II}$ & $\begin{array}{l}\text { Enzalutamide }+ \text { taselisib } \\
\text { (GDC-0032) }\end{array}$ & NA & NCT02457910 \\
\hline MEK & Metastatic & TNBC & II & Trametinib + GSK2141795 & NA & NCT01964924 \\
\hline HDAC & $\begin{array}{l}\text { Advanced or } \\
\text { recurrent }\end{array}$ & All & I & KHK2375 + exemestane & NA & NCT02623751 \\
\hline c-MET & Metastatic & TNBC & II & Cabozantinib & NA & NCT01738438 \\
\hline
\end{tabular}

BC: breast cancer; HER2: human epidermal growth factor receptor 2; HDAC: histone deacetylases; NA: not applicable; TNBC: triple-negative breast cancer.

In addition, a phase III double-blind randomized clinical study is currently enrolling patients with locally advanced or metastatic TNBC to investigate the benefit of capivasertib, another AKT inhibitor, with paclitaxel as first-line treatment (NCT03997123; CAPItello-290).

\subsection{Anti-Androgen Targeted Therapy}

A phase II clinical trial of bicalutamide, an androgen-blocking agent, was reported in patients with metastatic AR-positive TNBC (Table 3) [100]. Patients who showed more than $10 \%$ AR nuclear staining were considered to be AR positive. Among patients with AR-positive tumors, single treatment with bicalutamide showed a clinical benefits rate of $19 \%$, including complete or partial response, or stable disease more than 6 months. The median PFS was 12 weeks (range, 11-22 weeks). Single treatment with bicalutamide was well tolerated without high-grade adverse events. This study demonstrated the proof of concept for AR-targeted therapy in AR-positive TNBC.

Another phase II clinical trial with enzalutamide (Table 3), a new generation AR inhibitor, was reported in patients with advanced-stage AR-positive TNBC, and 55\% of them had high AR expression (immunohistochemistry $\geq 10 \%$ ) [101]. At 16 weeks, $35 \%$ of patients showed clinical benefits for enzalutamide.

There are various ongoing clinical trials for AR-targeted therapies with paclitaxel (NCT02689427) or palbociclib (NCT02605486) in metastatic TNBC (Table 3). Moreover, in a preclinical study on LAR-subtype TNBC, a relationship was shown between the PI3K/AKT pathway and AR-targeted therapy. A phase $\mathrm{Ib} / \mathrm{II}$ clinical trial is ongoing to evaluate the combination of taselisib, a PI3K inhibitor, and enzalutamide in metastatic TNBC (Table 3; NCT02457910). 


\subsection{Other Therapies}

Aberrant MEK activation and an abnormality of the RAS/MAPK pathway in TNBC and BLBC led to the combination of a MEK inhibitor and chemotherapies or other targeted therapies (Figure 1). A phase I clinical trial with gemcitabine and trametinib (an inhibitor of MEK1/2) was studied in patients with several solid tumors, including metastatic TNBC [102]. The overall response was not significant; however, the only pCR was shown in patients with metastatic TNBC. A phase II trial of single-agent trametinib followed by trametinib in combination with GSK2141795 (AKT inhibitor) is ongoing in patients with advanced TNBC (NCT01964924). There are many other approved clinical trials for metastatic TNBC. A histone deacetylase inhibitor is under evaluation as monotherapy (NCT02623751). In addition, a phase II clinical trial with a c-MET inhibitor (cabozantinib) was conducted for metastatic TNBC (NCT01738438).

\section{Conclusions}

The biggest obstacle in terms of drug development would be the heterogeneity of TNBC, leading to dissecting this $15 \%$ of whole breast cancers into small target populations to be studied in clinical trials. Nevertheless, successful targets have been found, including BRCA1/2, PD-L1, and Trop2, leading to the approval of PARP inhibitors, immune checkpoint inhibitors, and sacituzumab govitecan in recent years. HER2, AKT, and AR are also under investigation for use in the clinic. These struggles have yielded potential new treatments for this dismal and hard to treat subtype of breast cancers. More biologic dissection and subsequent tailored clinical trials are warranted for future success.

Author Contributions: Conceptualization, W.-J.R. and J.H.S.; writing-original draft preparation, W.-J.R.; writing-review and editing, W.-J.R. and J.H.S.; supervision, J.H.S. All authors have read and agreed to the published version of the manuscript.

Funding: This study was supported by Basic Science Research Program through the National Research Foundation of Korea (NRF) funded by the Ministry of Education (2021R1I1A1A01059173). This study also was supported in part by a faculty research grant from Yonsei University College of Medicine for 2014 (6-2014-0188). This study was supported by the National Cancer Center Grant, Korea (NCC-1810861).

Institutional Review Board Statement: Not applicable.

Informed Consent Statement: Not applicable.

Data Availability Statement: Data is contained within the article.

Acknowledgments: We thank K. Y. Choi for his advice on the article.

Conflicts of Interest: The authors declare no conflict of interest.

\section{Abbreviation}

$\mathrm{AR}$, androgen receptor; $\mathrm{ADC}$, antibody-drug conjugates; $\mathrm{BC}$, breast cancer; $\mathrm{BLBC}$, basal-like breast cancer; BL1, basal-like 1; BL2, basal-like 2; CDK, cyclin-dependent kinase; DUSP4, dual specificity phosphatase 4 gene; EGFR, epithelial growth factor receptor; ER, estrogen receptor; EMT, epithelial-mesenchymal transition; ERK, extracellular signal-regulated kinase; FDA, U.S. Food and Drug Administration; HER2, human epidermal growth factor receptor 2; HRD, homologous recombination deficiency; IM, immunomodulatory; IHC, immunohistochemistry; ISH, in situ hybridization; LAR, luminal androgen receptor; $\mathrm{M}$, mesenchymal; MAPK, mitogen-activated protein kinase; MSL, mesenchymal stem-like; MHC, major histocompatibility complex; mTOR, mechanistic target of rapamycin; NLR, neutrophil-lymphocyte ratio; OS, overall survival; ORR, overall response rates; PARP, poly (ADP-ribose) polymerase; $\mathrm{PCR}$, pathological complete response; $\mathrm{PR}$, progesterone receptor; PI3K, phosphoinositide 3-kinase; PFS, progression-free survival; PD-L1, programmed cell death ligand 1; PD-1, programmed cell death protein 1; RTK, receptor tyrosine kinases; RFS, recurrence-free survival; TNBC, triple-negative breast cancer; TIL, tumor infiltrating lymphocytes; TNT, triple- 
negative breast cancer trial; Trop2, trophoblast cell surface antigen 2; T-DXd, trastuzumab deruxtecan.

\section{References}

1. Dent, R.; Trudeau, M.; Pritchard, K.I.; Hanna, W.M.; Kahn, H.K.; Sawka, C.A.; Lickley, L.A.; Rawlinson, E.; Sun, P.; Narod, S.A. Triple-negative breast cancer: Clinical features and patterns of recurrence. Clin. Cancer Res. 2007, 13, 4429-4434. [CrossRef] [PubMed]

2. Perou, C.M.; Sørlie, T.; Eisen, M.B.; van de Rijn, M.; Jeffrey, S.S.; Rees, C.A.; Pollack, J.R.; Ross, D.T.; Johnsen, H.; Akslen, L.A.; et al. Molecular portraits of human breast tumours. Nature 2000, 406, 747-752. [CrossRef] [PubMed]

3. Sørlie, T.; Perou, C.M.; Tibshirani, R.; Aas, T.; Geisler, S.; Johnsen, H.; Hastie, T.; Eisen, M.B.; van de Rijn, M.; Jeffrey, S.S.; et al. Gene expression patterns of breast carcinomas distinguish tumor subclasses with clinical implications. Proc. Natl. Acad. Sci. USA 2001, 98, 10869-10874. [CrossRef]

4. The Cancer Genome Atlas Network. Comprehensive molecular portraits of human breast tumours. Nature 2012, 490, 61-70. [CrossRef] [PubMed]

5. Shah, S.P.; Roth, A.; Goya, R.; Oloumi, A.; Ha, G.; Zhao, Y.; Turashvili, G.; Ding, J.; Tse, K.; Haffari, G.; et al. The clonal and mutational evolution spectrum of primary triple-negative breast cancers. Nature 2012, 486, 395-399. [CrossRef]

6. Farmer, H.; McCabe, N.; Lord, C.J.; Tutt, A.N.; Johnson, D.A.; Richardson, T.B.; Santarosa, M.; Dillon, K.J.; Hickson, I.; Knights, C.; et al. Targeting the DNA repair defect in BRCA mutant cells as a therapeutic strategy. Nature 2005, 434, 917-921. [CrossRef]

7. Parker, J.S.; Mullins, M.; Cheang, M.C.; Leung, S.; Voduc, D.; Vickery, T.; Davies, S.; Fauron, C.; He, X.; Hu, Z.; et al. Supervised risk predictor of breast cancer based on intrinsic subtypes. J. Clin. Oncol. 2009, 27, 1160-1167. [CrossRef]

8. Cheang, M.C.; Martin, M.; Nielsen, T.O.; Prat, A.; Voduc, D.; Rodriguez-Lescure, A.; Ruiz, A.; Chia, S.; Shepherd, L.; Ruiz-Borrego, M.; et al. Defining breast cancer intrinsic subtypes by quantitative receptor expression. Oncologist 2015, 20, 474-482. [CrossRef]

9. Lehmann, B.D.; Bauer, J.A.; Chen, X.; Sanders, M.E.; Chakravarthy, A.B.; Shyr, Y.; Pietenpol, J.A. Identification of human triple-negative breast cancer subtypes and preclinical models for selection of targeted therapies. J. Clin. Investig. 2011, 121, 2750-2767. [CrossRef] [PubMed]

10. Loi, S.; Sirtaine, N.; Piette, F.; Salgado, R.; Viale, G.; Van Eenoo, F.; Rouas, G.; Francis, P.; Crown, J.P.; Hitre, E.; et al. Prognostic and predictive value of tumor-infiltrating lymphocytes in a phase III randomized adjuvant breast cancer trial in node-positive breast cancer comparing the addition of docetaxel to doxorubicin with doxorubicin-based chemotherapy: BIG 02-98. J. Clin. Oncol. 2013, 31, 860-867. [CrossRef] [PubMed]

11. Bianchini, G.; Balko, J.M.; Mayer, I.A.; Sanders, M.E.; Gianni, L. Triple-negative breast cancer: Challenges and opportunities of a heterogeneous disease. Nat. Rev. Clin. Oncol. 2016, 13, 674-690. [CrossRef] [PubMed]

12. Foulkes, W.D.; Stefansson, I.M.; Chappuis, P.O.; Bégin, L.R.; Goffin, J.R.; Wong, N.; Trudel, M.; Akslen, L.A. Germline BRCA1 mutations and a basal epithelial phenotype in breast cancer. J. Natl. Cancer Inst. 2003, 95, 1482-1485. [CrossRef] [PubMed]

13. Matros, E.; Wang, Z.C.; Lodeiro, G.; Miron, A.; Iglehart, J.D.; Richardson, A.L. BRCA1 promoter methylation in sporadic breast tumors: Relationship to gene expression profiles. Breast Cancer Res. Treat. 2005, 91, 179-186. [CrossRef] [PubMed]

14. Turner, N.C.; Reis-Filho, J.S. Basal-like breast cancer and the BRCA1 phenotype. Oncogene 2006, 25, 5846-5853. [CrossRef] [PubMed]

15. Miyashita, M.; Sasano, H.; Tamaki, K.; Chan, M.; Hirakawa, H.; Suzuki, A.; Tada, H.; Watanabe, G.; Nemoto, N.; Nakagawa, S.; et al. Tumor-infiltrating CD8+ and FOXP3+ lymphocytes in triple-negative breast cancer: Its correlation with pathological complete response to neoadjuvant chemotherapy. Breast Cancer Res. Treat. 2014, 148, 525-534. [CrossRef]

16. Martín, M. Platinum compounds in the treatment of advanced breast cancer. Clin. Breast Cancer 2001, 2, 190-208, discussion 209. [CrossRef]

17. Atchley, D.P.; Albarracin, C.T.; Lopez, A.; Valero, V.; Amos, C.I.; Gonzalez-Angulo, A.M.; Hortobagyi, G.N.; Arun, B.K. Clinical and pathologic characteristics of patients with BRCA-positive and BRCA-negative breast cancer. J. Clin. Oncol. 2008, 26, 4282-4288. [CrossRef]

18. Venkitaraman, A.R. Linking the cellular functions of BRCA genes to cancer pathogenesis and treatment. Annu. Rev. Pathol. 2009, 4, 461-487. [CrossRef]

19. Hilborn, E.; Gacic, J.; Fornander, T.; Nordenskjöld, B.; Stål, O.; Jansson, A. Androgen receptor expression predicts beneficial tamoxifen response in oestrogen receptor- $\alpha$-negative breast cancer. Br. J. Cancer 2016, 114, 248-255. [CrossRef]

20. Ali, H.R.; Glont, S.E.; Blows, F.M.; Provenzano, E.; Dawson, S.J.; Liu, B.; Hiller, L.; Dunn, J.; Poole, C.J.; Bowden, S.; et al. PD-L1 protein expression in breast cancer is rare, enriched in basal-like tumours and associated with infiltrating lymphocytes. Ann. Oncol. 2015, 26, 1488-1493. [CrossRef]

21. Mittendorf, E.A.; Philips, A.V.; Meric-Bernstam, F.; Qiao, N.; Wu, Y.; Harrington, S.; Su, X.; Wang, Y.; Gonzalez-Angulo, A.M.; Akcakanat, A.; et al. PD-L1 expression in triple-negative breast cancer. Cancer Immunol. Res. 2014, 2, 361-370. [CrossRef]

22. Adams, S.; Schmid, P.; Rugo, H.S.; Winer, E.P.; Loirat, D.; Awada, A.; Cescon, D.W.; Iwata, H.; Campone, M.; Nanda, R.; et al. Pembrolizumab monotherapy for previously treated metastatic triple-negative breast cancer: Cohort A of the phase II KEYNOTE-086 study. Ann. Oncol. 2019, 30, 397-404. [CrossRef] 
23. Adams, S.; Loi, S.; Toppmeyer, D.; Cescon, D.W.; De Laurentiis, M.; Nanda, R.; Winer, E.P.; Mukai, H.; Tamura, K.; Armstrong, A.; et al. Pembrolizumab monotherapy for previously untreated, PD-L1-positive, metastatic triple-negative breast cancer: Cohort B of the phase II KEYNOTE-086 study. Ann. Oncol. 2019, 30, 405-411. [CrossRef] [PubMed]

24. Cortes, J.; Cescon, D.W.; Rugo, H.S.; Nowecki, Z.; Im, S.A.; Yusof, M.M.; Gallardo, C.; Lipatov, O.; Barrios, C.H.; Holgado, E.; et al. Pembrolizumab plus chemotherapy versus placebo plus chemotherapy for previously untreated locally recurrent inoperable or metastatic triple-negative breast cancer (KEYNOTE-355): A randomised, placebo-controlled, double-blind, phase 3 clinical trial. Lancet 2020, 396, 1817-1828. [CrossRef]

25. Schmid, P.; Cortes, J.; Pusztai, L.; McArthur, H.; Kümmel, S.; Bergh, J.; Denkert, C.; Park, Y.H.; Hui, R.; Harbeck, N.; et al. Pembrolizumab for Early Triple-Negative Breast Cancer. N. Engl. J. Med. 2020, 382, 810-821. [CrossRef]

26. Winer, E.P.; Lipatov, O.; Im, S.A.; Goncalves, A.; Muñoz-Couselo, E.; Lee, K.S.; Schmid, P.; Tamura, K.; Testa, L.; Witzel, I.; et al. Pembrolizumab versus investigator-choice chemotherapy for metastatic triple-negative breast cancer (KEYNOTE-119): A randomised, open-label, phase 3 trial. Lancet Oncol. 2021, 22, 499-511. [CrossRef]

27. Schmid, P.; Adams, S.; Rugo, H.S.; Schneeweiss, A.; Barrios, C.H.; Iwata, H.; Diéras, V.; Hegg, R.; Im, S.A.; Shaw Wright, G.; et al. Atezolizumab and Nab-Paclitaxel in Advanced Triple-Negative Breast Cancer. N. Engl. J. Med. 2018, 379, 2108-2121. [CrossRef]

28. DiMeo, T.A.; Anderson, K.; Phadke, P.; Fan, C.; Perou, C.M.; Naber, S.; Kuperwasser, C. A novel lung metastasis signature links Wnt signaling with cancer cell self-renewal and epithelial-mesenchymal transition in basal-like breast cancer. Cancer Res. 2009, 69, 5364-5373. [CrossRef]

29. Kim, S.B.; Dent, R.; Im, S.A.; Espié, M.; Blau, S.; Tan, A.R.; Isakoff, S.J.; Oliveira, M.; Saura, C.; Wongchenko, M.J.; et al. Ipatasertib plus paclitaxel versus placebo plus paclitaxel as first-line therapy for metastatic triple-negative breast cancer (LOTUS): A multicentre, randomised, double-blind, placebo-controlled, phase 2 trial. Lancet Oncol. 2017, 18, 1360-1372. [CrossRef]

30. Nik-Zainal, S.; Davies, H.; Staaf, J.; Ramakrishna, M.; Glodzik, D.; Zou, X.; Martincorena, I.; Alexandrov, L.B.; Martin, S.; Wedge, D.C.; et al. Landscape of somatic mutations in 560 breast cancer whole-genome sequences. Nature 2016, 534, 47-54. [CrossRef] [PubMed]

31. Watkins, J.; Weekes, D.; Shah, V.; Gazinska, P.; Joshi, S.; Sidhu, B.; Gillett, C.; Pinder, S.; Vanoli, F.; Jasin, M.; et al. Genomic Complexity Profiling Reveals That HORMAD1 Overexpression Contributes to Homologous Recombination Deficiency in Triple-Negative Breast Cancers. Cancer Discov. 2015, 5, 488-505. [CrossRef] [PubMed]

32. Carey, L.; Winer, E.; Viale, G.; Cameron, D.; Gianni, L. Triple-negative breast cancer: Disease entity or title of convenience? Nat. Rev. Clin. Oncol. 2010, 7, 683-692. [CrossRef]

33. Park, H.S.; Jang, M.H.; Kim, E.J.; Kim, H.J.; Lee, H.J.; Kim, Y.J.; Kim, J.H.; Kang, E.; Kim, S.W.; Kim, I.A.; et al. High EGFR gene copy number predicts poor outcome in triple-negative breast cancer. Mod. Pathol. 2014, 27, 1212-1222. [CrossRef]

34. Shaffer, C. Trop2 deal heats up antibody-drug conjugate space in cancer. Nat. Biotechnol. 2021, 39, 128-130. [CrossRef] [PubMed]

35. Modi, S.; Park, H.; Murthy, R.K.; Iwata, H.; Tamura, K.; Tsurutani, J.; Moreno-Aspitia, A.; Doi, T.; Sagara, Y.; Redfern, C.; et al. Antitumor Activity and Safety of Trastuzumab Deruxtecan in Patients With HER2-Low-Expressing Advanced Breast Cancer: Results From a Phase Ib Study. J. Clin. Oncol. 2020, 38, 1887-1896. [CrossRef]

36. Lehmann, B.D.; Pietenpol, J.A. Identification and use of biomarkers in treatment strategies for triple-negative breast cancer subtypes. J. Pathol. 2014, 232, 142-150. [CrossRef] [PubMed]

37. Bertucci, F.; Finetti, P.; Cervera, N.; Charafe-Jauffret, E.; Mamessier, E.; Adélaïde, J.; Debono, S.; Houvenaeghel, G.; Maraninchi, D.; Viens, P.; et al. Gene expression profiling shows medullary breast cancer is a subgroup of basal breast cancers. Cancer Res. 2006, 66, 4636-4644. [CrossRef]

38. Burstein, M.D.; Tsimelzon, A.; Poage, G.M.; Covington, K.R.; Contreras, A.; Fuqua, S.A.; Savage, M.I.; Osborne, C.K.; Hilsenbeck, S.G.; Chang, J.C.; et al. Comprehensive genomic analysis identifies novel subtypes and targets of triple-negative breast cancer. Clin. Cancer Res. 2015, 21, 1688-1698. [CrossRef]

39. Jézéquel, P.; Kerdraon, O.; Hondermarck, H.; Guérin-Charbonnel, C.; Lasla, H.; Gouraud, W.; Canon, J.L.; Gombos, A.; Dalenc, F.; Delaloge, S.; et al. Identification of three subtypes of triple-negative breast cancer with potential therapeutic implications. Breast Cancer Res. 2019, 21, 65. [CrossRef]

40. Yun, M.H.; Hiom, K. CtIP-BRCA1 modulates the choice of DNA double-strand-break repair pathway throughout the cell cycle. Nature 2009, 459, 460-463. [CrossRef]

41. Ding, S.L.; Sheu, L.F.; Yu, J.C.; Yang, T.L.; Chen, B.F.; Leu, F.J.; Shen, C.Y. Abnormality of the DNA double-strand-break checkpoint/repair genes, ATM, BRCA1 and TP53, in breast cancer is related to tumour grade. Br. J. Cancer 2004, 90, $1995-2001$. [CrossRef] [PubMed]

42. Turner, N.C.; Reis-Filho, J.S.; Russell, A.M.; Springall, R.J.; Ryder, K.; Steele, D.; Savage, K.; Gillett, C.E.; Schmitt, F.C.; Ashworth, A.; et al. BRCA1 dysfunction in sporadic basal-like breast cancer. Oncogene 2007, 26, 2126-2132. [CrossRef]

43. Ibrahim, Y.H.; García-García, C.; Serra, V.; He, L.; Torres-Lockhart, K.; Prat, A.; Anton, P.; Cozar, P.; Guzmán, M.; Grueso, J.; et al. PI3K inhibition impairs BRCA1/2 expression and sensitizes BRCA-proficient triple-negative breast cancer to PARP inhibition. Cancer Discov. 2012, 2, 1036-1047. [CrossRef] [PubMed]

44. Barretina, J.; Caponigro, G.; Stransky, N.; Venkatesan, K.; Margolin, A.A.; Kim, S.; Wilson, C.J.; Lehár, J.; Kryukov, G.V.; Sonkin, D.; et al. The Cancer Cell Line Encyclopedia enables predictive modelling of anticancer drug sensitivity. Nature 2012, 483, 603-607. [CrossRef] [PubMed] 
45. Giltnane, J.M.; Balko, J.M. Rationale for targeting the Ras/MAPK pathway in triple-negative breast cancer. Discov. Med. 2014, 17, 275-283. [PubMed]

46. Hoeflich, K.P.; O’Brien, C.; Boyd, Z.; Cavet, G.; Guerrero, S.; Jung, K.; Januario, T.; Savage, H.; Punnoose, E.; Truong, T.; et al. In vivo antitumor activity of MEK and phosphatidylinositol 3-kinase inhibitors in basal-like breast cancer models. Clin. Cancer Res. 2009, 15, 4649-4664. [CrossRef]

47. Cerami, E.; Gao, J.; Dogrusoz, U.; Gross, B.E.; Sumer, S.O.; Aksoy, B.A.; Jacobsen, A.; Byrne, C.J.; Heuer, M.L.; Larsson, E.; et al. The cBio cancer genomics portal: An open platform for exploring multidimensional cancer genomics data. Cancer Discov. 2012, 2, 401-404. [CrossRef]

48. Duncan, J.S.; Whittle, M.C.; Nakamura, K.; Abell, A.N.; Midland, A.A.; Zawistowski, J.S.; Johnson, N.L.; Granger, D.A.; Jordan, N.V.; Darr, D.B.; et al. Dynamic reprogramming of the kinome in response to targeted MEK inhibition in triple-negative breast cancer. Cell 2012, 149, 307-321. [CrossRef]

49. Balko, J.M.; Cook, R.S.; Vaught, D.B.; Kuba, M.G.; Miller, T.W.; Bhola, N.E.; Sanders, M.E.; Granja-Ingram, N.M.; Smith, J.J.; Meszoely, I.M.; et al. Profiling of residual breast cancers after neoadjuvant chemotherapy identifies DUSP4 deficiency as a mechanism of drug resistance. Nat. Med. 2012, 18, 1052-1059. [CrossRef]

50. Balko, J.M.; Schwarz, L.J.; Bhola, N.E.; Kurupi, R.; Owens, P.; Miller, T.W.; Gómez, H.; Cook, R.S.; Arteaga, C.L. Activation of MAPK pathways due to DUSP4 loss promotes cancer stem cell-like phenotypes in basal-like breast cancer. Cancer Res. 2013, 73, 6346-6358. [CrossRef]

51. Gucalp, A.; Traina, T.A. Targeting the androgen receptor in triple-negative breast cancer. Curr. Probl. Cancer 2016, 40, 141-150. [CrossRef] [PubMed]

52. Niemeier, L.A.; Dabbs, D.J.; Beriwal, S.; Striebel, J.M.; Bhargava, R. Androgen receptor in breast cancer: Expression in estrogen receptor-positive tumors and in estrogen receptor-negative tumors with apocrine differentiation. Mod. Pathol. 2010, 23, 205-212. [CrossRef] [PubMed]

53. Park, S.; Koo, J.; Park, H.S.; Kim, J.H.; Choi, S.Y.; Lee, J.H.; Park, B.W.; Lee, K.S. Expression of androgen receptors in primary breast cancer. Ann. Oncol. 2010, 21, 488-492. [CrossRef] [PubMed]

54. Masuda, H.; Baggerly, K.A.; Wang, Y.; Zhang, Y.; Gonzalez-Angulo, A.M.; Meric-Bernstam, F.; Valero, V.; Lehmann, B.D.; Pietenpol, J.A.; Hortobagyi, G.N.; et al. Differential response to neoadjuvant chemotherapy among 7 triple-negative breast cancer molecular subtypes. Clin. Cancer Res. 2013, 19, 5533-5540. [CrossRef] [PubMed]

55. Asano, Y.; Kashiwagi, S.; Goto, W.; Tanaka, S.; Morisaki, T.; Takashima, T.; Noda, S.; Onoda, N.; Ohsawa, M.; Hirakawa, K.; et al. Expression and Clinical Significance of Androgen Receptor in Triple-Negative Breast Cancer. Cancers 2017, 9, 4. [CrossRef] [PubMed]

56. Narayanan, R.; Dalton, J.T. Androgen Receptor: A Complex Therapeutic Target for Breast Cancer. Cancers 2016, 8, 108. [CrossRef] [PubMed]

57. Shah, P.D.; Gucalp, A.; Traina, T.A. The role of the androgen receptor in triple-negative breast cancer. Womens Health 2013, 9 , 351-360. [CrossRef]

58. Basile, D.; Cinausero, M.; Iacono, D.; Pelizzari, G.; Bonotto, M.; Vitale, M.G.; Gerratana, L.; Puglisi, F. Androgen receptor in estrogen receptor positive breast cancer: Beyond expression. Cancer Treat. Rev. 2017, 61, 15-22. [CrossRef] [PubMed]

59. Pietri, E.; Conteduca, V.; Andreis, D.; Massa, I.; Melegari, E.; Sarti, S.; Cecconetto, L.; Schirone, A.; Bravaccini, S.; Serra, P.; et al. Androgen receptor signaling pathways as a target for breast cancer treatment. Endocr. Relat. Cancer 2016, 23, R485-R498. [CrossRef]

60. Gonzalez-Angulo, A.M.; Stemke-Hale, K.; Palla, S.L.; Carey, M.; Agarwal, R.; Meric-Berstam, F.; Traina, T.A.; Hudis, C.; Hortobagyi, G.N.; Gerald, W.L.; et al. Androgen receptor levels and association with PIK3CA mutations and prognosis in breast cancer. Clin. Cancer Res. 2009, 15, 2472-2478. [CrossRef]

61. Stemke-Hale, K.; Gonzalez-Angulo, A.M.; Lluch, A.; Neve, R.M.; Kuo, W.L.; Davies, M.; Carey, M.; Hu, Z.; Guan, Y.; Sahin, A.; et al. An integrative genomic and proteomic analysis of PIK3CA, PTEN, and AKT mutations in breast cancer. Cancer Res. 2008, 68, 6084-6091. [CrossRef]

62. Sharma, P.; Klemp, J.R.; Kimler, B.F.; Mahnken, J.D.; Geier, L.J.; Khan, Q.J.; Elia, M.; Connor, C.S.; McGinness, M.K.; Mammen, J.M.; et al. Germline BRCA mutation evaluation in a prospective triple-negative breast cancer registry: Implications for hereditary breast and/or ovarian cancer syndrome testing. Breast Cancer Res. Treat. 2014, 145, 707-714. [CrossRef] [PubMed]

63. Pineda, B.; Diaz-Lagares, A.; Pérez-Fidalgo, J.A.; Burgués, O.; González-Barrallo, I.; Crujeiras, A.B.; Sandoval, J.; Esteller, M.; Lluch, A.; Eroles, P. A two-gene epigenetic signature for the prediction of response to neoadjuvant chemotherapy in triple-negative breast cancer patients. Clin. Epigenetics 2019, 11, 33. [CrossRef] [PubMed]

64. Charafe-Jauffret, E.; Ginestier, C.; Iovino, F.; Wicinski, J.; Cervera, N.; Finetti, P.; Hur, M.H.; Diebel, M.E.; Monville, F.; Dutcher, J.; et al. Breast cancer cell lines contain functional cancer stem cells with metastatic capacity and a distinct molecular signature. Cancer Res. 2009, 69, 1302-1313. [CrossRef]

65. Creighton, C.J.; Li, X.; Landis, M.; Dixon, J.M.; Neumeister, V.M.; Sjolund, A.; Rimm, D.L.; Wong, H.; Rodriguez, A.; Herschkowitz, J.I.; et al. Residual breast cancers after conventional therapy display mesenchymal as well as tumor-initiating features. Proc. Natl. Acad. Sci. USA 2009, 106, 13820-13825. [CrossRef] [PubMed]

66. Harrison, H.; Farnie, G.; Howell, S.J.; Rock, R.E.; Stylianou, S.; Brennan, K.R.; Bundred, N.J.; Clarke, R.B. Regulation of breast cancer stem cell activity by signaling through the Notch4 receptor. Cancer Res. 2010, 70, 709-718. [CrossRef] 
67. Liu, S.; Dontu, G.; Mantle, I.D.; Patel, S.; Ahn, N.S.; Jackson, K.W.; Suri, P.; Wicha, M.S. Hedgehog signaling and Bmi-1 regulate self-renewal of normal and malignant human mammary stem cells. Cancer Res. 2006, 66, 6063-6071. [CrossRef] [PubMed]

68. Marotta, L.L.; Almendro, V.; Marusyk, A.; Shipitsin, M.; Schemme, J.; Walker, S.R.; Bloushtain-Qimron, N.; Kim, J.J.; Choudhury, S.A.; Maruyama, R.; et al. The JAK2/STAT3 signaling pathway is required for growth of CD44 ${ }^{+} \mathrm{CD} 24^{-}$stem cell-like breast cancer cells in human tumors. J. Clin. Investig. 2011, 121, 2723-2735. [CrossRef]

69. Ryu, W.J.; Lee, J.D.; Park, J.C.; Cha, P.H.; Cho, Y.H.; Kim, J.Y.; Sohn, J.H.; Paik, S.; Choi, K.Y. Destabilization of $\beta$-catenin and RAS by targeting the Wnt/ $\beta$-catenin pathway as a potential treatment for triple-negative breast cancer. Exp. Mol. Med. 2020, 52, 832-842. [CrossRef]

70. Ibrahim, E.M.; Al-Foheidi, M.E.; Al-Mansour, M.M.; Kazkaz, G.A. The prognostic value of tumor-infiltrating lymphocytes in triple-negative breast cancer: A meta-analysis. Breast Cancer Res. Treat. 2014, 148, 467-476. [CrossRef]

71. Brown, S.D.; Warren, R.L.; Gibb, E.A.; Martin, S.D.; Spinelli, J.J.; Nelson, B.H.; Holt, R.A. Neo-antigens predicted by tumor genome meta-analysis correlate with increased patient survival. Genome Res. 2014, 24, 743-750. [CrossRef] [PubMed]

72. Dieci, M.V.; Criscitiello, C.; Goubar, A.; Viale, G.; Conte, P.; Guarneri, V.; Ficarra, G.; Mathieu, M.C.; Delaloge, S.; Curigliano, G.; et al. Prognostic value of tumor-infiltrating lymphocytes on residual disease after primary chemotherapy for triple-negative breast cancer: A retrospective multicenter study. Ann. Oncol. 2014, 25, 611-618. [CrossRef] [PubMed]

73. Ono, M.; Tsuda, H.; Shimizu, C.; Yamamoto, S.; Shibata, T.; Yamamoto, H.; Hirata, T.; Yonemori, K.; Ando, M.; Tamura, K.; et al. Tumor-infiltrating lymphocytes are correlated with response to neoadjuvant chemotherapy in triple-negative breast cancer. Breast Cancer Res. Treat. 2012, 132, 793-805. [CrossRef] [PubMed]

74. Denkert, C.; Loibl, S.; Noske, A.; Roller, M.; Müller, B.M.; Komor, M.; Budczies, J.; Darb-Esfahani, S.; Kronenwett, R.; Hanusch, C.; et al. Tumor-associated lymphocytes as an independent predictor of response to neoadjuvant chemotherapy in breast cancer. $J$. Clin. Oncol. 2010, 28, 105-113. [CrossRef] [PubMed]

75. Baker, K.; Lachapelle, J.; Zlobec, I.; Bismar, T.A.; Terracciano, L.; Foulkes, W.D. Prognostic significance of CD8+ T lymphocytes in breast cancer depends upon both oestrogen receptor status and histological grade. Histopathology 2011, 58, 1107-1116. [CrossRef]

76. De Larco, J.E.; Wuertz, B.R.; Furcht, L.T. The potential role of neutrophils in promoting the metastatic phenotype of tumors releasing interleukin-8. Clin. Cancer Res. 2004, 10, 4895-4900. [CrossRef]

77. Queen, M.M.; Ryan, R.E.; Holzer, R.G.; Keller-Peck, C.R.; Jorcyk, C.L. Breast cancer cells stimulate neutrophils to produce oncostatin M: Potential implications for tumor progression. Cancer Res. 2005, 65, 8896-8904. [CrossRef]

78. Yamanaka, T.; Matsumoto, S.; Teramukai, S.; Ishiwata, R.; Nagai, Y.; Fukushima, M. The baseline ratio of neutrophils to lymphocytes is associated with patient prognosis in advanced gastric cancer. Oncology 2007, 73, 215-220. [CrossRef]

79. Bae, S.J.; Cha, Y.J.; Yoon, C.; Kim, D.; Lee, J.; Park, S.; Cha, C.; Kim, J.Y.; Ahn, S.G.; Park, H.S.; et al. Prognostic value of neutrophil-to-lymphocyte ratio in human epidermal growth factor receptor 2-negative breast cancer patients who received neoadjuvant chemotherapy. Sci. Rep. 2020, 10, 13078. [CrossRef]

80. Pistelli, M.; De Lisa, M.; Ballatore, Z.; Caramanti, M.; Pagliacci, A.; Battelli, N.; Ridolfi, F.; Santoni, M.; Maccaroni, E.; Bracci, R.; et al. Pre-treatment neutrophil to lymphocyte ratio may be a useful tool in predicting survival in early triple negative breast cancer patients. BMC Cancer 2015, 15, 195. [CrossRef]

81. Patel, D.A.; Xi, J.; Luo, J.; Hassan, B.; Thomas, S.; Ma, C.X.; Campian, J.L. Neutrophil-to-lymphocyte ratio as a predictor of survival in patients with triple-negative breast cancer. Breast Cancer Res. Treat. 2019, 174, 443-452. [CrossRef]

82. Sledge, G.W., Jr.; Loehrer, P.J., Sr.; Roth, B.J.; Einhorn, L.H. Cisplatin as first-line therapy for metastatic breast cancer. J. Clin. Oncol. 1988, 6, 1811-1814. [CrossRef] [PubMed]

83. Davies, H.; Glodzik, D.; Morganella, S.; Yates, L.R.; Staaf, J.; Zou, X.; Ramakrishna, M.; Martin, S.; Boyault, S.; Sieuwerts, A.M.; et al. HRDetect is a predictor of BRCA1 and BRCA2 deficiency based on mutational signatures. Nat. Med. 2017, 23, 517-525. [CrossRef]

84. Kennedy, R.D.; Quinn, J.E.; Mullan, P.B.; Johnston, P.G.; Harkin, D.P. The role of BRCA1 in the cellular response to chemotherapy. J. Natl. Cancer Inst. 2004, 96, 1659-1668. [CrossRef] [PubMed]

85. Isakoff, S.J.; Mayer, E.L.; He, L.; Traina, T.A.; Carey, L.A.; Krag, K.J.; Rugo, H.S.; Liu, M.C.; Stearns, V.; Come, S.E.; et al. TBCRC009: A Multicenter Phase II Clinical Trial of Platinum Monotherapy With Biomarker Assessment in Metastatic Triple-Negative Breast Cancer. J. Clin. Oncol. 2015, 33, 1902-1909. [CrossRef] [PubMed]

86. Tutt, A.; Tovey, H.; Cheang, M.C.U.; Kernaghan, S.; Kilburn, L.; Gazinska, P.; Owen, J.; Abraham, J.; Barrett, S.; Barrett-Lee, P.; et al. Carboplatin in BRCA1/2-mutated and triple-negative breast cancer BRCAness subgroups: The TNT Trial. Nat. Med. 2018, 24, 628-637. [CrossRef] [PubMed]

87. Yuan, Y.; Lee, J.S.; Yost, S.E.; Li, S.M.; Frankel, P.H.; Ruel, C.; Schmolze, D.; Robinson, K.; Tang, A.; Martinez, N.; et al. Phase II Trial of Neoadjuvant Carboplatin and Nab-Paclitaxel in Patients with Triple-Negative Breast Cancer. Oncologist 2021, 26, e382-e393. [CrossRef] [PubMed]

88. Iwase, M.; Ando, M.; Aogi, K.; Aruga, T.; Inoue, K.; Shimomura, A.; Tokunaga, E.; Masuda, N.; Yamauchi, H.; Yamashita, T.; et al. Long-term survival analysis of addition of carboplatin to neoadjuvant chemotherapy in HER2-negative breast cancer. Breast Cancer Res. Treat. 2020, 180, 687-694. [CrossRef]

89. Denkert, C.; von Minckwitz, G.; Brase, J.C.; Sinn, B.V.; Gade, S.; Kronenwett, R.; Pfitzner, B.M.; Salat, C.; Loi, S.; Schmitt, W.D.; et al. Tumor-infiltrating lymphocytes and response to neoadjuvant chemotherapy with or without carboplatin in human epidermal growth factor receptor 2-positive and triple-negative primary breast cancers. J. Clin. Oncol. 2015, 33, 983-991. [CrossRef] 
90. Audebert, M.; Salles, B.; Calsou, P. Involvement of poly(ADP-ribose) polymerase-1 and XRCC1/DNA ligase III in an alternative route for DNA double-strand breaks rejoining. J. Biol. Chem. 2004, 279, 55117-55126. [CrossRef]

91. Tentori, L.; Graziani, G. Chemopotentiation by PARP inhibitors in cancer therapy. Pharmacol. Res. 2005, 52, 25-33. [CrossRef]

92. Robson, M.; Im, S.A.; Senkus, E.; Xu, B.; Domchek, S.M.; Masuda, N.; Delaloge, S.; Li, W.; Tung, N.; Armstrong, A.; et al. Olaparib for Metastatic Breast Cancer in Patients with a Germline BRCA Mutation. N. Engl. J. Med. 2017, 377, 523-533. [CrossRef]

93. Litton, J.K.; Rugo, H.S.; Ettl, J.; Hurvitz, S.A.; Gonçalves, A.; Lee, K.H.; Fehrenbacher, L.; Yerushalmi, R.; Mina, L.A.; Martin, M.; et al. Talazoparib in Patients with Advanced Breast Cancer and a Germline BRCA Mutation. N. Engl. J. Med. 2018, 379, 753-763. [CrossRef]

94. Bardia, A.; Mayer, I.A.; Vahdat, L.T.; Tolaney, S.M.; Isakoff, S.J.; Diamond, J.R.; O'Shaughnessy, J.; Moroose, R.L.; Santin, A.D.; Abramson, V.G.; et al. Sacituzumab Govitecan-hziy in Refractory Metastatic Triple-Negative Breast Cancer. N. Engl. J. Med. 2019, 380, 741-751. [CrossRef]

95. Kalbasi, A.; Ribas, A. Tumour-intrinsic resistance to immune checkpoint blockade. Nat. Rev. Immunol. 2020, 20, 25-39. [CrossRef]

96. Goldenberg, D.M.; Cardillo, T.M.; Govindan, S.V.; Rossi, E.A.; Sharkey, R.M. Trop-2 is a novel target for solid cancer therapy with sacituzumab govitecan (IMMU-132), an antibody-drug conjugate (ADC). Oncotarget 2015, 6, 22496-22512. [CrossRef]

97. Cubas, R.; Zhang, S.; Li, M.; Chen, C.; Yao, Q. Trop2 expression contributes to tumor pathogenesis by activating the ERK MAPK pathway. Mol. Cancer 2010, 9, 253. [CrossRef] [PubMed]

98. Fernandez Vallone, V.; Leprovots, M.; Strollo, S.; Vasile, G.; Lefort, A.; Libert, F.; Vassart, G.; Garcia, M.I. Trop2 marks transient gastric fetal epithelium and adult regenerating cells after epithelial damage. Development 2016, 143, 1452-1463. [CrossRef] [PubMed]

99. Bardia, A.; Mayer, I.A.; Diamond, J.R.; Moroose, R.L.; Isakoff, S.J.; Starodub, A.N.; Shah, N.C.; O’Shaughnessy, J.; Kalinsky, K.; Guarino, M.; et al. Efficacy and Safety of Anti-Trop-2 Antibody Drug Conjugate Sacituzumab Govitecan (IMMU-132) in Heavily Pretreated Patients With Metastatic Triple-Negative Breast Cancer. J. Clin. Oncol. 2017, 35, 2141-2148. [CrossRef] [PubMed]

100. Gucalp, A.; Tolaney, S.; Isakoff, S.J.; Ingle, J.N.; Liu, M.C.; Carey, L.A.; Blackwell, K.; Rugo, H.; Nabell, L.; Forero, A.; et al. Phase II trial of bicalutamide in patients with androgen receptor-positive, estrogen receptor-negative metastatic Breast Cancer. Clin. Cancer Res. 2013, 19, 5505-5512. [CrossRef] [PubMed]

101. Traina, T.A.; Miller, K.; Yardley, D.A.; Eakle, J.; Schwartzberg, L.S.; O’Shaughnessy, J.; Gradishar, W.; Schmid, P.; Winer, E.; Kelly, C.; et al. Enzalutamide for the Treatment of Androgen Receptor-Expressing Triple-Negative Breast Cancer. J. Clin. Oncol. 2018, 36, 884-890. [CrossRef] [PubMed]

102. Infante, J.R.; Papadopoulos, K.P.; Bendell, J.C.; Patnaik, A.; Burris, H.A., 3rd; Rasco, D.; Jones, S.F.; Smith, L.; Cox, D.S.; Durante, M.; et al. A phase 1b study of trametinib, an oral Mitogen-activated protein kinase kinase (MEK) inhibitor, in combination with gemcitabine in advanced solid tumours. Eur. J. Cancer 2013, 49, 2077-2085. [CrossRef] [PubMed] 